\title{
Neonatal Seizures with Diffuse Cerebral White Matter Lesions on Magnetic Resonance Imaging Associated with Rotavirus Infection: A Report of Three Cases
}

Min Seon Choi, Sang Kee Park, and Jae Hee Lee

Department of Pediatrics, Chosun University College of Medicine, Gwangju, Korea

\section{ABSTRACT}

Rotavirus is the major cause of gastroenteritis in children under the age of 5 . Rotavirus infection may lead to several neurological complications as meningitis, encephalitis, convulsion, encephalopathy, hemorrhagic shock, central pontine myelinolysis, GuillainBarre syndrome, and Reye's syndrome. Further, some reports have described diffuse cerebral white matter lesions on diffusion-weighted magnetic resonance imaging (MRI) in neonates with rotavirus induced seizures. Here, we report on three neonates with rotavirus induced seizures with cerebral white matter abnormalities on MRI.

Key Words: Newborn, Seizure, Diffusion magnetic resonance imaging, Rotavirus

서론

로타바이러스 감염과 관련된 중추신경계 합병증에 대한 보고는 Salmi 등 ${ }^{1)}$ 에 의해 처음으로 보 고되었으며, 이후 신생아에서도 서맥, 무호흡, 경련, 뇌수막염과 뇌증이 보고되어 로타바이러스 감염이 신생아에서 중추신경계 합병증을 일으킬 수 있음이 알려졌다 ${ }^{2,3)}$.

최근 신생아에서 로타바이러스 감염과 관련하여 발생한 뇌백질의 이상 소견에 대한 보고가 있으며, 뇌 자기공명영상(magnetic resonance imaging, MRI)에서 대뇌겉질에는 병변을 보이지 않으면서, 확산강조영상에서 심부 대뇌백질에 고신호 강도를 보이는 특징적인 소견들이 관찰되 었다. 대부분 생후 4 일에서 6일 사이에 경련이 발생하였으며 장기적인 신경학적 예후를 봤을 때 정상 발달을 보이는 경우도 있으나 뇌백질 연화증이나 뇌위축을 보이면서 발달 장애가 동반되 기도 하였다 ${ }^{4,5)}$.

저자들은 생후 4-5일째 다른 경련의 원인이 없이 로타바이러스 감염으로 인한 경련이 있었던 환자들에서 뇌 MRI에서 뇌겉질은 정상이나 확산강조영상에서 양측 뇌 백질에 대칭적인 고신호 강도를 보였던 증례들을 경험하였기에 문헌고찰과 함께 보고하고자 한다.
Received: 27 November 2017

Revised: 2 May 2018

Accepted: 18 May 2018

Correspondence to: Jae Hee Lee

Department of Pediatrics, Chosun University College of Medicine, 365 Pilmun-daero, Dong-gu, Gwangju 61453, Korea

Tel: +82-62-220-3069

Fax: +82-62-227-2904

E-mail: pedjhl@chosun.ac.kr

Copyright(c)

By Korean Society of Neonatology.

All right reserved.

This is an Open-Access article distributed under the terms of the Creative Commons Attribution Non-Commercial License (http://creativecommons.org/licenses/ by-nc/4.0), which permits unrestricted non-commercial use, distribution, and reproduction in any medium, provided the original work is properly cited. 
증례

\section{1. 증례 1}

재태 연령 36주 4일, 출생 체중 $2.94 \mathrm{~kg}$ 으로 분만력 2-0-0-2인 39세 산모에서 조기진통이 있어 제왕절개로 개인병원에서 태어난 남아 로, 아프가 점수는 1 분과 5 분에 각각 10 점이었다. 분만 중이나 출생 후 특이 소견은 없었다. 환자는 생후 4 일째에 10 여 초간 지속되는 전 신성 간대성 경련이 4차례 있어 전원 되었다. 가족력 및 산과력에서 특이 소견 없었다. 입원 시 활력징후는 혈압 $75 / 34 \mathrm{~mm} \mathrm{Hg}$, 맥박 124 회/분, 체온 $36.3^{\circ} \mathrm{C}$, 호흡수 50 회/분이었다. 체중은 $2.78 \mathrm{~kg}$ 이었으며 무른 변을 보고 있었으나, 수유량은 양호하였고 구토나 발열, 무호흡 은 없었다. 말초혈액 검사에서 혈색소 $17.1 \mathrm{~g} / \mathrm{dL}$, 백혈구 $9,140 / \mathrm{mm}^{3}$, 혈소판 $147,000 / \mathrm{mm}^{3}$ 이었고, 전해질 검사에서 나트륨 $137 \mathrm{mEq} / \mathrm{L}$, 칼 륨 $4.3 \mathrm{mEq} / \mathrm{L}$, 혈당은 $71.5 \mathrm{mg} / \mathrm{dL}$ 이었다. 생화학 및 면역혈청 검사 에서 총 단백질 $4.65 \mathrm{~g} / \mathrm{dL}$, 알부민 $3.19 \mathrm{~g} / \mathrm{dL}$, 간기능 검사 $35.7 / 12.4$ $\mathrm{U} / \mathrm{L}$, 혈액요소질소 $5.7 \mathrm{mg} / \mathrm{dL}$, 이온화된 칼슘/총 칼슘 $4.3 / 7.21 \mathrm{mg} /$ $\mathrm{dL}$, 인 $6.48 \mathrm{mg} / \mathrm{dL}, \mathrm{C}$-반응단백 (정상치 $\leq 0.3 \mathrm{mg} / \mathrm{dL}$ ) $0.08 \mathrm{mg} / \mathrm{dL}$
이었다. 뇌척수액 검사에서 백혈구 $7 / \mathrm{mm}^{3}$, 단백질 $88.4 \mathrm{mg} / \mathrm{dL}$, 당 농도 $38.1 \mathrm{mg} / \mathrm{dL}$ 이었으며, 세균배양 검사에서 균이 동정 되지 않 았다. 대변항원 검사(enzyme immunoassay kits, RIDASCREEN ${ }^{\circledR}$ ROTAVIRUS, Darmstadt, Germany)에서는 로타바이러스 양성이었 다. 입원 중에 시행한 선천성 대사이상 검사는 정상이었다. 입원 1 일 째와 2 일째 수십 초간 지속되는 전신성 간대성 경련 1차례, 입맛을 다시는 듯 쩝쩝거리면서 자전거 페달을 밟는 듯한 경련이 2차례 발 생하여 amplitude-integrated electroencephalography (a-EEG) 모니 터링을 하면서 페노바르비탈(phenobarbital)을 투여했다. 뇌파 검사 에서 오른쪽 측두부와 양측 중앙부에서 다수의 예파가 관찰되었으 며, 뇌 MRI 확산강조영상에서 양측 뇌실주위백질의 신호 증가 소견 을 보였다(Figure 1A), 환자는 더 이상의 경련은 없고 대변 양상도 호 전되어 입원 10 일째에 페노바르비탈을 복용하면서 퇴원하였다. 한 달 뒤 외래에서 시행한 뇌 MRI에서 양측 전두부의 낭성 뇌실주위백 질 연화증을 보였다(Figure $2 \mathrm{~A}$ ). 환자는 출생 후 4 개월째 경련이 없 으며 뇌파검사에서 정상 소견을 보여 항경련제 치료를 중단하였고, 만 1세 때 추적한 뇌 MRI에서는 낭성 병변은 흡수되었으나 뇌실주

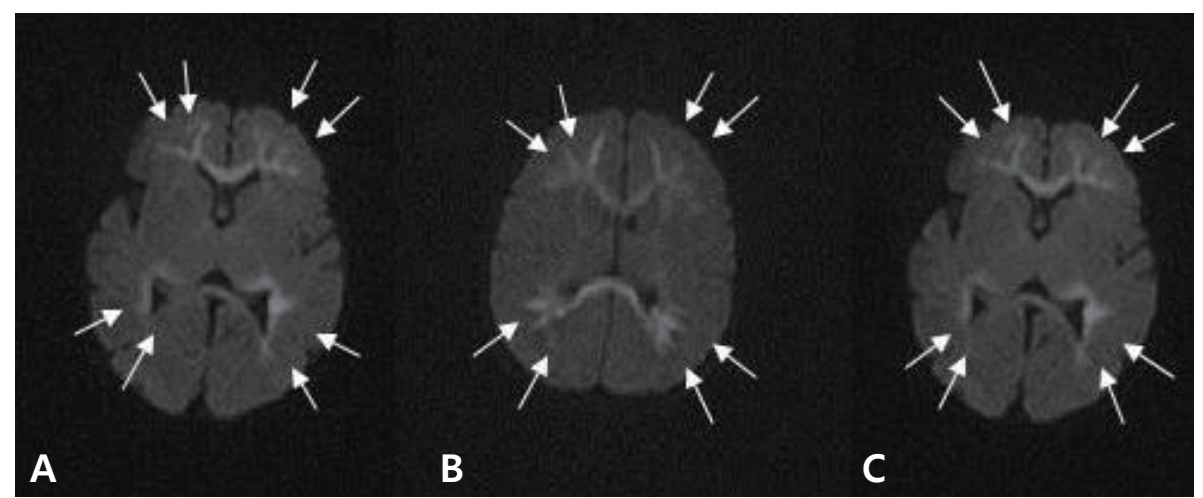

Figure 1. Diffusion-weighted brain magnetic resonance imagings of the three patients after seizure onset (A, patient 1; B, patient 2; C, patient 3) show diffuse high signal intensities (arrows) with diffusion restriction in both periventricular white matter of lateral ventricles.

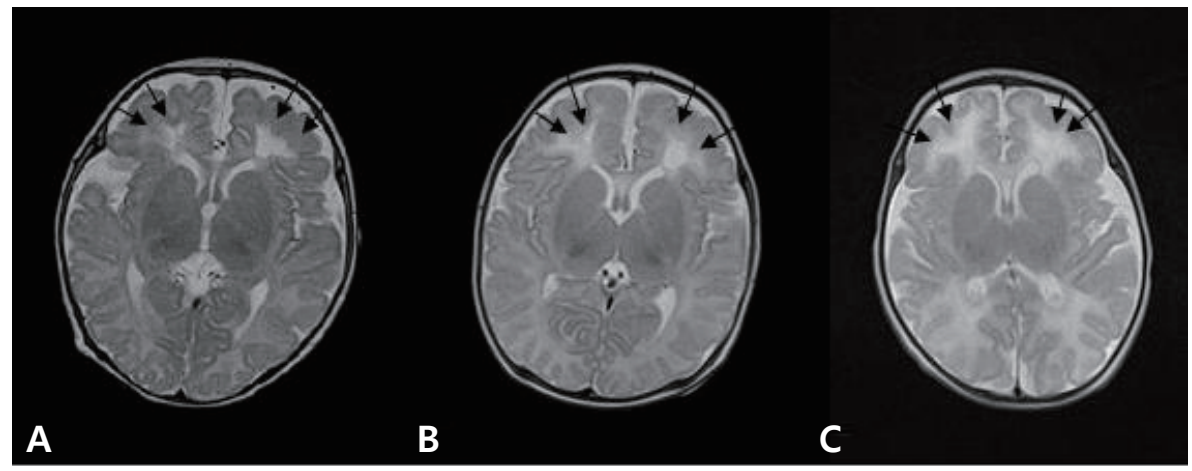

Figure 2. Brain magnetic resonance imagings of the three patients at one month after onset of patients (A, patient 1 ; B, patient 2; C, patient 3 ) show cystic periventricular leukomalacia (arrows) in both frontal lobes. 


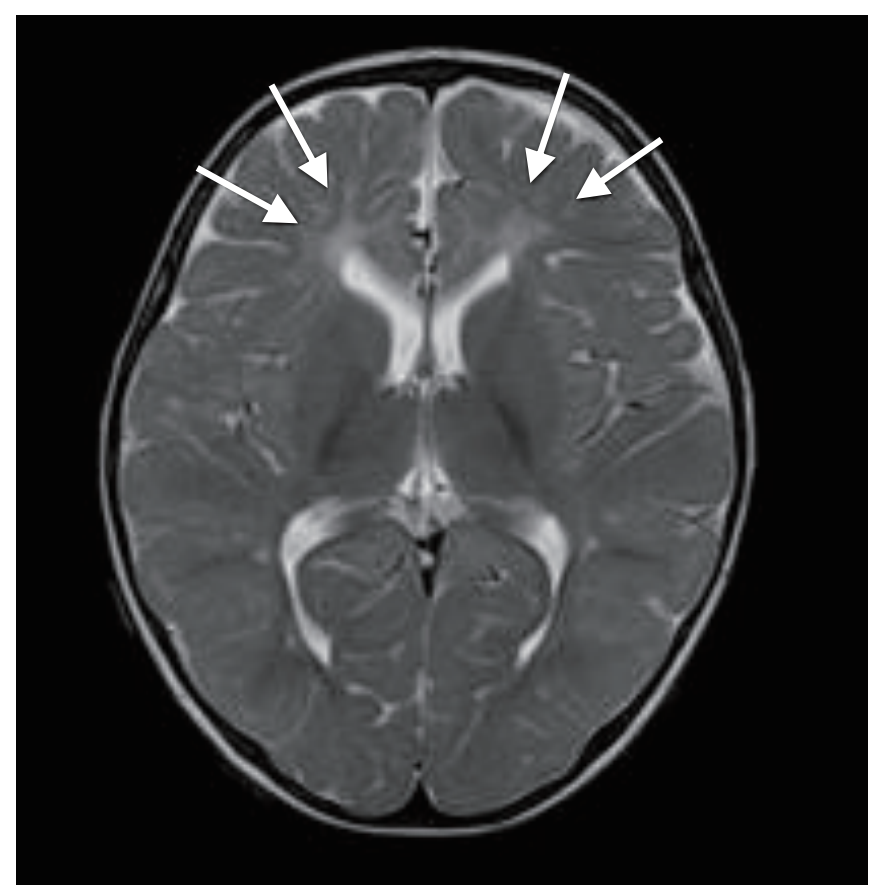

Figure 3. Brain magnetic resonance imaging of patient 1 at 1 year after onset shows high signal intensity lesions (arrows) at the periventricular area in both frontal lobes.

위백질의 연화증을 보였다(Figure 3). 환자는 현재 2세 7개월로 체중 $12.5 \mathrm{~kg}$ (10-25 백분위수), 신장 $91 \mathrm{~cm}$ (25-50 백분위수), 두위 $48 \mathrm{~cm}$ (10-25 백분위수)이며 한국영유아발달선별검사에서 정상 발달을 보 이고 있다.

\section{2. 증례 2}

재태 연령 36주 5일, 출생 체중 $2.88 \mathrm{~kg}$ 으로 분만력 2-0-0-2인 34 세 산모에서 조기진통이 있어 제왕절개로 개인병원에서 태어난 남 아로, 아프가 점수는 1 분과 5 분에 각각 10 점이었다. 분만 중에 특별 한 외상력은 없었고 출생 후 특이 소견도 없었으나, 생후 4 일째 수십 초간 지속되는 전신성 간대성 경련이 3 차례(각각 20초, 15 초, 1 분)있 어 전원 되었다. 산모는 15 년 전 뇌전증으로 한 달여간 치료받은 과 거력이 있었으나, 현재는 아무런 약물치료 없이 건강했다. 입원 시 활력징후는 혈압 $72 / 46 \mathrm{~mm} \mathrm{Hg}$, 맥박 126 회/분, 체온 $36.9^{\circ} \mathrm{C}$, 호흡수 66회/분이었다. 체중은 $2.8 \mathrm{~kg}$ 이었으며 환자는 발열, 구토, 그리고 무호흡의 증상은 없었고 수유량과 소변 배출이 양호하고 신체 검진 에서도 탈수를 의심할 만한 소견을 보이지는 않았으나 무른 변이 지 속되고 있었다. 신경학적 검사에서도 이상 소견을 보이지 않았으며 근육긴장도와 반사도 정상이었다. 전혈구계산치, 전해질 검사, 이온 화된 칼슘 및 총 칼슘, 생화학 검사, C-반응단백, 선천성 대사이상 검 사는 정상이었다. 뇌척수액 검사에서 정상이었고, 세균배양 검사에 서도 균이 동정 되지 않았다. 대변항원 검사에서는 로타바이러스 양 성이었다. 입원 후에도 수십 초간 지속되는 전신성 간대성 경련이
10여 초간 2차례 발생하여 a-EEG 모니터링을 하면서 페노바르비탈 을 투여하였으며 이후 경련의 재발은 없었다. 뇌파 검사에서 오른쪽 측두부에서 예파와 극파가, 양쪽 중앙부에 약간의 예파가 관찰되었 다. 뇌 MRI 확산강조영상에서 양측 뇌실주위백질의 신호 증가 소견 을 보였다(Figure 1B). 입원 7일째에 환자는 더 이상 경련이 없으며 무른 변도 호전을 보여서 페노바르비탈의 복용을 지속하며 퇴원하 였다. 한 달 뒤 추적한 뇌 MRI에서 양측 전두부의 낭성 뇌실주위백 질 연화증을 보였다(Figure 2B). 환자는 퇴원 두 달 후에도 경련이 없 으며 뇌파 검사에서 정상 소견을 보여 항경련제 치료를 중단하였다. 추적 뇌 MRI는 보호자의 거부로 더 이상 시행하지 못했으나 현재 2 세 7개월로 체중 $14 \mathrm{~kg}$ (50-75 백분위수), 신장 $90 \mathrm{~cm}$ (25-50 백분위 수)이며, 한국영유아발달선별검사에서 정상 발달을 보이고 있다.

\section{3. 증례 3}

재태 연령 37주 4일, 출생 체중 $2.96 \mathrm{~kg}$ 으로 분만력 1-0-0-1인 30세 산모에서 자연분만으로 개인병원에서 태어난 여아로, 아프가 점수 는 1 분과 5 분에 각각 10 점이었다. 분만 중이나 출생 후 특이 소견 없 었으며 생후 2 일째부터 수유량이 감소하고, 구토와 무른 변이 있었 으며 생후 5 일째 40 여 초간 지속되는 국소성 간대성 경련이 있어 전 원 되었다. 가족력 및 산과력에서 특이 소견이 없었다. 입원 시 활력 징후는 혈압 $78 / 46 \mathrm{~mm} \mathrm{Hg}$, 맥박 150 회/분, 체온 $36.4^{\circ} \mathrm{C}$, 호흡수 56 회/분이었다. 체중은 $2.66 \mathrm{~kg}$ 이었으며 발열이나 무호흡은 없었다. 전혈구계산치, 전해질 검사, 이온화된 칼슘 및 총 칼슘, 생화학 검사, C-반응단백, 선천성 대사이상 검사는 정상이었다. 뇌척수액 검사에 서 백혈구 $0 / \mathrm{mm}^{3}$, 단백질 $85.3 \mathrm{mg} / \mathrm{dL}$, 당 농도 $66.2 \mathrm{mg} / \mathrm{dL}$ 이었으며, 세균배양 검사에서 균 동정 되지 않았다. 대변항원 검사에서는 로타 바이러스 양성이었다. 입원 후 10 여 초간 지속되는 국소성 간대성 경 련이 1차례 발생하여 a-EEG 모니터링을 하면서 페노바르비탈을 투 여했으며 이후 경련 재발은 없었다. 뇌파 검사에서 오른쪽 측두부에 약간의 예파와 왼쪽 중앙부와 측두부에 간헐적으로 예파가 관찰되 었으며, 뇌 MRI 확산강조영상에서 양측 뇌실주위백질의 신호 증가 소견을 보였다(Figure 1C). 환자는 경련이 없고 전신상태 양호하여 입원 6일째 페노바르비탈 복용하면서 퇴원했다. 한 달 뒤 외래에서 시행한 뇌 MRI에서 양측 전두부의 낭성 뇌실주위백질 연화증을 보 였다(Figure 2C). 항경련제를 복용 중이며 역연령 4 개월에 외래를 통 해 발달평가 및 추후 뇌 MRI를 추적할 예정이다.

\section{고찰}

로타바이러스는 영아와 특히 5 세 미만 소아에서 급성 위장관염을 일으키는 주된 원인 바이러스로 감염은 주로 위장관에 국한되어 생 각되었다. 로타바이러스 감염은 여러 합병증을 동반할 수 있는데 탈 
수가 가장 흔하며, 간염이나 괴사성 장염과 같은 장내 합병증을 동반 하기도 한다 ${ }^{6}$. 그리고 장외 합병증도 보고 되어 있으며 ${ }^{7}$, 뇌수막염, 뇌염, 열을 동반하거나 동반하지 않은 경련, 뇌병증, 출혈성 쇼크, 중 심 뇌교 용해증(central pontine myelinolysis), 길랭-바레증후군, 라 이증후군과 같은 신경학적 합병증도 보고되고 있다 ${ }^{8)}$.

신생아에서의 로타바이러스 감염은 영아나 소아에서의 감염과 비 교해 일반적으로 무증상이거나 증상이 있어도 경한 경우가 대부분 이다" 또한 로타바이러스 감염으로 인한 중추신경계 합병증도 대개 6 개월에서 3 세 사이의 영아와 어린 소아에서 좀 더 흔하지만, 신생아 에서도 서맥, 무호흡, 경련, 뇌수막염과 뇌증이 보고되었다 ${ }^{2,3)}$.

로타바이러스 감염으로 인한 경련을 보이는 신생아에서 뇌 MRI 확산강조영상에서 특징적인 양측의 대칭성 뇌백질의 확산 제한 음 영을 보이는 증례들이 지속적으로 보고되고 있으며 그 연관성에 관 한 연구들이 제기되고 있다 ${ }^{10,11}$.

로타바이러스로 인한 경련을 보였던 만삭의 신생아 30명을 대상 으로 한 Lee 등 ${ }^{5}$ 의 연구에서 13명의 환자가 뇌 MRI 확산강조영상에 서 뇌백질의 병변을 보였고 특징적으로 뇌겉질은 정상이었다. 그리 고 이 환자들 모두 생후 4 일에서 6 일 사이에 경련이 발생하였다. 추 후 뇌 $\mathrm{MRI}$ 를 추적한 10 명 중 4 명에서 뇌위축이나 뇌백질의 연화증 을 보였고, 발달 추적이 이루어진 10명 중 3 명에서 언어나 운동 발달 의 장애를 보였다. 본원에서 경험한 환자들도 생후 4-5일 사이에 경 련을 보였으며, 3 명 모두 뇌 MRI 확산강조영상에서 심부 대뇌백질 에 고신호 강도를 보이면서 대뇌겉질에는 병변을 보이지 않아 기존 연구 대상자들에게서 관찰된 특징적인 소견과 일치하였다. 로타바 이러스 감염 기간 동안 경련을 보인 5 명의 미숙아와 3 명의 만삭 신 생아를 대상으로 한 Verboon-Maciolek 등 ${ }^{4}$ 의 연구에서 4 명의 미숙 아에서 뇌 MRI에서 낭성 병변과 뇌백질의 고신호 강도가 관찰되었 으며 2 명의 만삭아 에서도 낭성 변화를 동반한 국소 병변이 관찰되 었다. 4 명의 미숙아에서 발달장애나 뇌성마비를 보였으나 3 명의 만 삭아는 9에서 12 개월에 시행한 발달 상태가 정상이었다. 특히 미숙 아에서 교정연령으로 34-36주인 출생 후 21일에서 42일 사이에 로 타바이러스에 감염되어 경련이나 무호흡, 처침과 같은 신경학적 증 상을 보였던 증례들에서 뇌실주위백질 연화증을 보였는데, 이는 심 부 대뇌백질이 후기 조산아 시기에 감염이 발생했을 때 좀 더 취약하 기 때문으로 생각된다. 로타바이러스 감염 후에 위장관계의 증상을 보이기까지 1-2일의 잠복기가 있고, 발작은 일반적으로 영유아에서 설사가 나타난 후 1 일에서 5 일 사이에 발생한다고 알려져 왔다 ${ }^{12)}$. 따 라서 출생 후 얼마 되지 않은 시기에 로타바이러스 감염이 있었다면 경련이 출생 후 5일 전후에 발생한 이유를 설명할 수 있다. 후기 조 산아나 만삭아를 대상으로 했던 연구들에서 로타바이러스 감염으로 인한 경련을 보이면서 뇌 MRI 확산강조영상에서 심부 대뇌백질에 손상을 보였던 환자들은 모두 생후 4-6일 사이에 경련을 보이고 있 었으며 본원에서 경험한 증례들 또한 생후 4-5일 사이에 경련을 보
였다. Kim 등 ${ }^{13)}$ 의 연구에서도 경련을 보인 전체 144 명의 신생아를 대상으로 경련 증상을 보인 17 명과 경련 증상이 없었던 127 명의 환 아를 대상으로 봤을 때, 경련 증상을 보인 환아들은 경련이 없던 환 아들에 비해 경련 이외의 구토나 발열 등 다른 임상 증상이 거의 없 었으며, 로타바이러스 항원 검출 시기가 경련이 없었던 환아들에 비 해 통계적으로 의미 있게 빨랐다. 본원에서 경험한 증례들 또한 모 든 증례에서 발열이 동반되지 않았고 3 번째 증례를 제외하고는 경련 외에 특이 증상이 없었으며, 세 증례 모두 출생 후 초기에 로타바이 러스 감염에 노출된 것으로 판단된다. 국내의 증례 보고 중에는 만 삭아에서 생후 7일경에 로타바이러스 감염으로 인한 경련을 보인 신 생아에서 경련 전에 발열이 지속되었던 경우도 보고되어 있다 ${ }^{14)}$. 위 증례에서도 본원의 첫 번째 증례와 같이 뇌실주위백질 연화증을 보 이나 생후 17 개월경의 신경학적 발달은 정상 소견을 보였다. 본 증 례들은 출생 후 4-5일 사이에 로타바이러스로 인한 경련을 보이면 서 뇌 MRI 확산강조영상에서 뇌백질의 손상을 보였던 후기 조산아 와 만삭아를 대상으로 비교적 장기적인 예후와 뇌 MRI 병변의 추적 이 이루어졌다.

Verboon-Maciolek 등 ${ }^{15,16)}$ 에 의한 연구에서 로타바이러스 외에 도 human parechovirus나 enterovirus 감염 후에도 경련과 뇌백질 의 손상이 동반되는 등 유사한 증상을 보였으나 parechovirus나 enterovirus 감염 후에는 발열이나 피부에 발진이 더 많이 동반되는 경향을 보였다. 따라서 급성 바이러스 감염으로 인한 뇌백질의 손상 (뇌실주위백질 연화증)은 특정 바이러스 감염에 의해서 발생하기보 다는 바이러스 감염에 취약한 신생아기 뇌백질의 특성과 관련된 반 응에 의한다고 해석할 수 있다.

특이한 점은 대부분의 로타바이러스 감염으로 경련이 있었던 신 생아에서 뇌척수액의 백혈구, 단백질, 당 농도 등이 대부분 정상 소 견을 보였다는 점이다. 이것은 로타바이러스 장염과 동반되어 영아 와 어린 소아에서 발생하는 양성 경련에서도 마찬가지다 ${ }^{17)}$. 본 증례 의 경우 혈액이나 뇌척수액에서 로타바이러스 중합효소연쇄반응 검 사를 시행하지 못했으나 이전 연구들에서도 혈액이나 뇌척수액에서 로타바이러스가 검출되지 않아도 신경 증상을 보였다 ${ }^{18,19)}$. 로타바이 러스 감염으로 인한 신경계 합병증의 발생 기전은 명확하지 않으나 로타바이러스에 의한 직접적인 신경계 감염이 원인이라는 설과 바 이러스의 특정 단백질(NSP4)에 의한 이차적 영향이라는 가설이 있 다 ${ }^{14)}$. 로타바이러스 소뇌염에서는 뇌척수액 내에 interleukin-6와 자 유 활성산소가 염증 과정에 관여하는 것으로 보인다 ${ }^{20)}$.

전해질 불균형이나 대사 이상, 뇌출혈이나 경색과 같은 뇌혈관질 환 등의 이상 없이 특히 생후 5 일경에 경련을 보이는 신생아에서 발 열이나 장염 증상의 유무와 상관없이 로타바이러스 감염에 의한 경 련과 뇌 병변의 가능성을 염두에 두고, 뇌 영상검사 및 발달평가의 추적이 필요하다. 그리고 미숙아의 경우 로타바이러스 감염으로 뇌 백질 연화증이 합병될 가능성이 만삭아에 비해 높으므로 신생아중 
환자실과 같은 취약한 환경에서는 로타바이러스 전파를 막기 위한 예방적 노력이 필요할 것으로 생각된다.

\section{감사의 글}

이 논문은 2017년도 조선대학교병원 선택진료 학술연구비에 의 하여 연구되었음.

\section{REFERENCES}

1) Salmi TT, Arstila P, Koivikko A. Central nervous system involvement in patients with rotavirus gastroenteritis. Scand J Infect Dis 1978;10:29-31.

2) de Villiers FP, Steele AD, Driessen M. Central nervous system involvement in neonatal rotavirus infection. Ann Trop Paediatr 2003;23:309-12.

3) Pager C, Steele D, Gwamanda P, Driessen M. A neonatal death associated with rotavirus infection: detection of rotavirus dsRNA in the cerebrospinal fluid. S Afr Med J 2000;90:364-5.

4) Verboon-Maciolek MA, Truttmann AC, Groenendaal F, Skranes J, Dollner H, Hunt RW, et al. Development of cystic periventricular leukomalacia in newborn infants after rotavirus infection. J Pediatr 2012;160:165-8.e1.

5) Lee KY, Oh KW, Weon YC, Choi SH. Neonatal seizures accompanied by diffuse cerebral white matter lesions on diffusionweighted imaging are associated with rotavirus infection. Eur J Paediatr Neurol 2014;18:624-31.

6) Parashar UD, Burton A, Lanata C, Boschi-Pinto C, Shibuya K, Steele D, et al. Global mortality associated with rotavirus disease among children in 2004. J Infect Dis 2009;200 Suppl 1:S9-S15.

7) Lynch M, Lee B, Azimi P, Gentsch J, Glaser C, Gilliam S, et al. Rotavirus and central nervous system symptoms: cause or contaminant? Case reports and review. Clin Infect Dis 2001;33: 932-8.

8) Iturriza-Gomara M, Auchterlonie IA, Zaw W, Molyneaux P, Desselberger U, Gray J. Rotavirus gastroenteritis and central nervous system (CNS) infection: characterization of the VP7 and VP4 genes of rotavirus strains isolated from paired fecal and cerebrospinal fluid samples from a child with CNS disease. J Clin Microbiol 2002;40:4797-9.

9) Santosham M, Pathak A, Kottapalli S, Vergara J, Wong SJ, Frochlick J, et al. Neonatal rotavirus infection. Lancet 1982;1:10701.

10) Oh KW, Moon CH, Lee KY. Association of rotavirus with seizures accompanied by cerebral white matter injury in neonates. J Child Neurol 2015;30:1433-9.

11) Yeom JS, Kim YS, Seo JH, Park JS, Park ES, Lim JY, et al. Distinctive pattern of white matter injury in neonates with rotavirus infection. Neurology 2015;84:21-7.

12) Cusmai R, Jocic-Jakubi B, Cantonetti L, Japaridze N, Vigevano F. Convulsions associated with gastroenteritis in the spectrum of benign focal epilepsies in infancy: 30 cases including four cases with ictal EEG recording. Epileptic Disord 2010;12:255-61.

13) Kim HA, Jo CK, Kim MJ. Neonatal seizures accompanied by cerebral white matter injury associated with rotavirus infection. Perinatology 2016;27:168-73.

14) Park JN, Park HA, Shin YH, Hwang JH. Rotavirus-induced neonatal seizures with cerebral white matter abnormalities on magnetic resonance imaging: a case report. Neonatal Med 2017; 24:45-8.

15) Verboon-Maciolek MA, Groenendaal F, Cowan F, Govaert $P$, van Loon AM, de Vries LS. White matter damage in neonatal enterovirus meningoencephalitis. Neurology 2006;66:1267-9.

16) Verboon-Maciolek MA, Groenendaal F, Hahn CD, Hellmann J, van Loon AM, Boivin G, et al. Human parechovirus causes encephalitis with white matter injury in neonates. Ann Neurol 2008;64:266-73.

17) Yorulmaz A, Sert S, Yilmaz FH. Evaluation of benign afebrile convulsions in 16 children with rotavirus gastroenteritis. Acta Neurol Belg 2017;117:441-5.

18) Takanashi J, Miyamoto T, Ando N, Kubota T, Oka M, Kato Z, et al. Clinical and radiological features of rotavirus cerebellitis. AJNR Am J Neuroradiol 2010;31:1591-5.

19) Nakagomi T, Nakagomi O. Rotavirus antigenemia in children with encephalopathy accompanied by rotavirus gastroenteritis. Arch Virol 2005;150:1927-31.

20) Kawashima $H$, Inage $Y$, Ogihara $M$, Kashiwagi $Y$, Takekuma $K$, Hoshika A, et al. Serum and cerebrospinal fluid nitrite/nitrate levels in patients with rotavirus gastroenteritis induced convulsion. Life Sci 2004;74:1397-405. 